\title{
CEO Succession Within Public Enterprises in Uganda: A Phenomenology of Middle Managers' Experiences
}

\author{
Samuel Luzobe \\ Eastern University \\ Franklin Oikelome \\ Eastern University
}

This paper explores the experiences of middle managers during a leadership succession within public enterprises in Uganda. Using a descriptive phenomenological approach involving in-depth interviews of middle managers across 5 public enterprises, the study found that middle managers sensed impending change, grappled with the rationale for change, exhibited a variety of emotions and experienced altered relationships with supervisors and subordinates. Basically, the findings indicated that middle managers are impacted by CEO succession in an African context and this situation has implications for organizational performance. Whereas middle managers who went through a smooth CEO succession were motivated, engaged and committed to the organization, it was the opposite in difficult CEO transitions where the supervisory role of the middle managers also declined. It is therefore important that the government, board and senior management in public enterprises involve middle managers in key processes of CEO succession.

Keywords: CEO succession, leadership, middle managers, public enterprises

\section{INTRODUCTION}

Chief Executive Officer (CEO) succession is a vital organizational decision, unique in scope and of incomparable importance (Charan, 2005; Costa, 2013, Finkelstein, Hambrick, \& Canella, 2009; Russel, 2014). CEO change is a defining moment for every organization, affecting all types of constituents at every level (Changati \& Sambharya, 1987; Charan, 2005; Jauch, Osborne, \& Glueck, 1980; Kesner \& Sebora, 1994; Ojeka, Adetula, Mukoro, \& Kpokpo, 2017). For all organizational members, the CEO transition is the most pervasive change (Dawley, Hoffman, \& Smith, 2004). CEO succession is recognized as a strategic action with potential to transform an organization's direction and vision (LeCounte, Prieto \& Phipps, 2017). In his seminal work, Grusky (1961) argued that leadership/CEO succession was important because it was closely associated with organizational stability; occurs in all organizations; and all organizations needed to manage it effectively. Moreover, succession events are unambiguous in what they are and when they occur (Giambatista et al., 2005), presenting a typical phenomenon for social inquiry.

Although CEO succession studies exist, little empirical research has addressed its effects on organizational members. The few studies that have considered the individual experiences of employees have focused on the top management team (Kesner \& Dalton, 1994; Schwendinger, 2011; Serra \& Borzillo, 2013). Despite MMs substantially influencing the company (Hutzschenreuter, Kleindienst \& Greger, 2012; 
Wooldridge, Schmid, \& Floyd, 2008), there is a paucity of studies on experiences of employees going through a CEO succession at these levels. Much of CEO succession research is conducted in the developed nations (Abdulwaheed, 2013; Adewale, Abolaji \& Kolade, 2011; Froese \& Bebenroth, 2012), with limited studies in the developing economies. Despite an extensive search, there was no scholarly article found on CEO succession in Uganda. Although PEs were estimated to contribute $10 \%$ of global GDP, there is a dearth of empirical research in regard to CEO succession in state-owned enterprises (Bruton, Peng, Ahlstrom, Stan, \& Xu, 2015). To address this gap in the literature, using a phenomenological approach within the peculiarity of the social cultural dynamics of Uganda and the unique business and leadership models of the PEs, this study investigated the experiences of middle managers during a CEO succession.

\section{BACKGROUND}

CEO succession is identified as an event, process or episode, which leads to the change of the top leader and includes the subsequent stabilization phase (Ballinger and Schoorman, 2007; Hutzschenreuter, 2012; Santora, Clemens \& Sarros, 1997). Research findings on leadership succession suggest that it can have a positive effect on performance (Boyne, James, John, \& Petrovsky, 2011; Davidson, Worre \& Dutia, 1993; Karg, McDonald, \& Schoenberg, 2015); a negative effect (Boyne et al., 2011; Grusky, 1963; Haveman, 1993; Lockmer, 2014; Soebbing \& Washington, 2011) or be inconsequential (Adler, Berry, \& Doherty, 2013; Boeker, 1992; Brown, 1982; Gamson \& Scotch, 1964). This has engendered three contending theories of leadership succession: the common sense (positive effect), the vicious cycle (negative impact), and the ritual scapegoating (no effect). Although the three theories suggest that the performance effect is enacted through employees' reactions to CEO succession, most of the studies use financial performance as the dependent variable (Haveman, Russo, \& Meyer, 2001; Intintoli, 2013; Sakano \& Lewin, 1999; Weng \& Lin, 2014).

There are contradictions and inconsistencies in the three theories of succession in relation to the effect of a CEO change on organizational performance. This has opened up research possibilities of integrating the three theories of leadership succession and anchoring them within organizational and strategic management theory (Giambatista et al., 2005; Rowe et al., 2005; Swidler \& Li, 2013). While there is emphasis on the centrality of the contribution of MMs in organizational change (Balogun \& Johnson, 2004; Floyd \& Wooldridge, 1994), contradictions and tensions related to the experiences of MMs as both targets of top-down changes and agents of change from the bottom up persist (Conway \& Monks, 2011). Several studies allude to different emotions (including uncertainty, fear, anger, and disempowerment) that MMs experience during organizational change (Herzig \& Jimmieson 2006; Johnson \& Härtel, 2014; Vakola \& Nikolaou, 2005).

Research on CEO succession in Africa is in its infancy, with pioneering work by scholars in Zimbabwe (Maphosa, 1999), Nigeria (Dauda, 2013), and Kenya (Timbe \& Sira, 2013). These studies point to the limited attention given to leadership succession issues and the politicization of leadership succession in PEs. Existing findings suggest there are two dominant and divergent views held by scholars on African leadership: the authoritarian/paternalistic and the collectivist/ humane orientated (Masango, 2002; Mbigi 2002). The African culture is unique in the way employees experience a leadership succession which may be reflective of the wider societal culture including the culture of political succession (Jackson, 2002; Jackson \& Yavuz, 2008; Kuada, 2010). Political interference is seen as contributing to the CEO changes within PEs and the performance of PEs has been dismal due to political interference (Volpin, 2008, Kickert, 2014; Kanyeihamba, 2012, Kauzya, 2008, Kabiru, Theuri \& Misiko, 2018; Adam 2014).

Against this backdrop, this study examined how MMs experienced a CEO succession at selected PEs in Uganda. The research question is as follows: What were the experiences of MMs that went through a CEO succession within PEs in Uganda? The set of sub-questions is: (i) How do the selected MMs describe their experiences of going through a CEO succession? (ii)How were the experiences of MMs during a CEO succession influenced/modified by pre-succession factors? (iii)How did MMs experience the internal organizational dynamics during a CEO succession? (iv)How did the MMs respond to the external factors (cultural, political, governance, social) that were impinging on the CEO succession process in the 
organization? (v) What are the universal essences of the experience of going through a CEO succession as described by the MMs?

\section{METHODOLOGY}

The study utilized transcendental phenomenology (descriptive, pure), a qualitative research method. This approach developed by Edmund Husserl (1859-1938) purposes to reduce individual experiences of a phenomenon to a description of a universal essence (Creswell, 2006). The method was selected because the study is exploratory, given the paucity of research addressed to experiences of MMs during a CEO succession. CEO succession studies have largely been quantitative (Kesner \& Sebora, 1994; Giambatista, Rowe, \& Riaz 2005). Yet, the qualitative research paradigm appears better suited in generating meanings that leaders and followers ascribe to significant events in the organizations such as CEO change (Klenke, 2008, p. 4). Swanson-Kauffman and Schonwald (1988) advanced that transcendental phenomenology was more apt in inquiries aimed at discovering universal aspects of a phenomenon that has either never been conceptualized, or that has been partially conceptualized. Additionally, transcendental phenomenology offered systematic data collection procedures and a rigorous data analysis approach.

In identifying PEs for the study, purposive sampling was adopted. A list of PEs was obtained from the Uganda Ministry of Finance. The list had 61 entities. Following the OECD (2015) guidelines (which view PEs as entities whose activities are largely of economic nature), 49 entities were selected. Twelve (12) of these had had CEO changes in the last 30 months preceding the study. Maximum variation sampling was then used as below:

(a) Age of organization - the youngest and oldest PE (b) Recency of CEO change-most recent and least recent (c) Size of organization (number of staff)- largest and smallest. Table 1 summarizes information about the selected PEs.

TABLE 1

CHARACTERISTICS OF SELECTED ORGANIZATIONS FOR THE STUDY

\begin{tabular}{|l|l|l|l|l|l|}
\hline Public Enterprise & $\begin{array}{l}\text { Year } \\
\text { set up }\end{array}$ & Employees & $\begin{array}{l}\text { Selected } \\
\text { participants }\end{array}$ & $\begin{array}{l}\text { CEO change } \\
\text { (months ago) }\end{array}$ & Industry \\
\hline $\begin{array}{l}\text { Uganda Broadcasting } \\
\text { Corporation }\end{array}$ & 2004 & 500 & 4 & 13 & Media \\
\hline $\begin{array}{l}\text { Uganda Electricity } \\
\text { Generation Company }\end{array}$ & 2001 & 115 & 3 & 20 & Engineering \\
\hline Uganda Tourism Board & 1994 & 20 & 2 & 29 & Tourism \\
\hline $\begin{array}{l}\text { Uganda Revenue } \\
\text { Authority }\end{array}$ & 1991 & 2900 & 4 & 22 & $\begin{array}{l}\text { Financial } \\
\text { services }\end{array}$ \\
\hline $\begin{array}{l}\text { National Housing and } \\
\text { Construction Company }\end{array}$ & 1964 & 150 & 4 & 10 & Construction \\
\hline
\end{tabular}

For the participants, purposeful sampling which aims at identifying information rich cases was used (Patton, 2002). The criteria for selecting participants were as follows: must have gone through the CEO change; been at the level of middle management when the change occurred; willing to participate in the interviews and capable of expressing oneself. Twenty (20) participants were initially selected for the study; only 17 consented. In phenomenology, there is no universally accepted sample size, though some scholars have recommended 2 to 25 participants (Klenke, 2003). Table 2 summarises the characteristics of the sample. 
TABLE 2

DEMOGRAPHIC INFORMATION ABOUT PARTICIPANTS IN THE STUDY

\begin{tabular}{|l|l|l|l|l|l|l|}
\hline & Code & Department & Gender & Age & Education background & Tenure \\
\hline 1 & $09-11-A$ & Finance & M & 37 & B Com, ACCA (finalist) & 4 \\
\hline 2 & $09-11-B$ & Internal Audit & F & 46 & B Com (accounting) & 21 \\
\hline 3 & $10-11-A$ & Broadcasting & F & 56 & BA(SS), Dip Journalism & 10 \\
\hline 4 & $10-11-B$ & Quality Assurance & F & 48 & BA, MBA, Dip Accounts & 20 \\
\hline 5 & $11-11-A$ & Broadcasting & F & 55 & B Mass communication & 12 \\
\hline 6 & $11-11-B$ & Broadcasting & M & 37 & B Mass communication & 16 \\
\hline 7 & $11-11-C$ & Legal & M & 37 & LLB, LLM, Dip Leg practice & 7 \\
\hline 8 & $15-11-A$ & Technical support & M & 54 & BSc, PGD & 24 \\
\hline 9 & $16-11-A$ & Legal & M & 33 & LLB, Dip Legal practice & 6 \\
\hline 10 & $16-11-B$ & Finance & F & 39 & B Com, ACCA, & 9 \\
\hline 11 & $16-11-C$ & Estates Management & F & 26 & BSc (Survey), PGD (PPM) & 3 \\
\hline 12 & $16-11-D$ & Broadcasting & M & 33 & B Mass communication & 7 \\
\hline 13 & $22-11-A$ & Administration & M & 53 & BBA, MSc (Procurement) & 7 \\
\hline 14 & $22-11-B$ & Finance & F & 48 & B Com, MSc(Fin), & 22 \\
\hline 15 & $23-11-A$ & Administration & F & 58 & UDBS, BBA, MMS, & 8 \\
\hline 16 & $30-11-A$ & Marketing & F & 47 & B Tourism, PGD Mkt & 12 \\
\hline 17 & $30-11-B$ & Research & M & 32 & B Tourism & 6 \\
\hline
\end{tabular}

\section{DATA COLLECTION AND ANALYSIS}

Data were collected using in-depth (face-to face) qualitative interviewing. In line with descriptive phenomenology, data collection was undergirded by three processes: phenomenological reduction (epoche/bracketing), description and search for essence (Klenke, 2003). Under reduction, the investigator reconstructed MM's experiences of a CEO succession and as much as possible, avoided contamination of data with personal experience. Klenke (2003) noted that perfect reduction is impossible and was therefore not the pursuit of this study.

Participants were encouraged to describe their lived experience in the most direct way, avoiding constructs of society and intellect (Klenke, 2003). An open-ended interview guide molded along the research questions was used to kick-start the interview. The researcher listened deeply, probing for clarifications. Participants were encouraged to give a full description of their experience of a CEO succession including feelings, images, and the context in which it occurred. Each participant was interviewed twice. The first interviews lasted 60 minutes on average and the second about 45 minutes. Interviews were audio-taped and transcribed by the researcher. Consent to audio-tape was obtained from each participant. The second interview was done after listening to the first one, enabling the researcher to identify gaps for the second interview. The two interview scripts from each participant were merged, furnishing 17 scripts. Before data analysis each participant received their merged script to validate it. All participants who reviewed their scripts confirmed the accuracy.

Data were analyzed using Colaizzi's (1978) data analysis method which is associated with descriptive phenomenology (Cohen et al., 2000). The seven-step process is shown in table 3. 


\section{TABLE 3 \\ STEPS IN COLAIZZI'S DESCRIPTIVE PHENOMENOLOGICAL METHOD}

\begin{tabular}{|l|l|}
\hline Step & Description \\
\hline Familiarization & $\begin{array}{l}\text { The researcher familiarizes him/herself with the data, by reading } \\
\text { through the participants' accounts several times }\end{array}$ \\
\hline $\begin{array}{l}\text { Identifying significant } \\
\text { statements }\end{array}$ & $\begin{array}{l}\text { The researcher identifies all statements in the accounts that are of } \\
\text { direct relevance to the phenomenon under investigation }\end{array}$ \\
\hline Formulating Meanings & $\begin{array}{l}\text { The researcher identifies meanings relevant to the phenomenon that } \\
\text { arise from a careful consideration of the significant statements. The } \\
\text { researcher must reflexively "bracket" his or her pre-suppositions to } \\
\text { stick closely to the phenomenon as experienced. }\end{array}$ \\
\hline Clustering themes & $\begin{array}{l}\text { The researcher clusters the identified meanings into themes that are } \\
\text { common across all accounts. Again, bracketing of pre-suppositions } \\
\text { is crucial, to avoid any potential influence of existing theory. }\end{array}$ \\
\hline $\begin{array}{l}\text { Developing an exhaustive } \\
\text { Description }\end{array}$ & $\begin{array}{l}\text { The researcher writes a full and inclusive description of the } \\
\text { phenomenon, incorporating all the themes produced at step 4. }\end{array}$ \\
\hline $\begin{array}{l}\text { Producing the fundamental } \\
\text { Structure }\end{array}$ & $\begin{array}{l}\text { The researcher condenses the exhaustive description down to a } \\
\text { short, dense statement that captures just those aspects deemed to be } \\
\text { essential to the structure of the phenomenon. }\end{array}$ \\
\hline $\begin{array}{l}\text { Seeking verification of the } \\
\text { fundamental Structure }\end{array}$ & $\begin{array}{l}\text { The researcher returns the fundamental statement to all participants } \\
\text { to ask whether it captures their experience. }\end{array}$ \\
\hline
\end{tabular}

Each transcript was scrutinised and statements that had a direct bearing to the phenomenon under investigation were highlighted. 732 significant statements were generated. 795 meanings were formulated by giving a general restatement to the significant statements (Colaizzi, 1978). Some significant statements generated more than one meaning. The formulated meanings were organized into 29 theme clusters. The theme clusters were organized into 4 major themes:

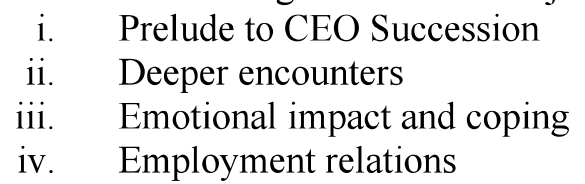

Using the themes and formulated meanings, a 14-page exhaustive description of the phenomenon was developed. From the exhaustive description, a fundamental statement (essence of the experience), was generated (one page). The fundamental statement was returned to the 17 participants for verification. Overall, they agreed the document represented their experiences.

\section{FINDINGS}

The findings are summarized as themes and cluster themes (see Table 4). 
TABLE 4

THEMATIC MAP: THEMES AND CLUSTER THEMES

\begin{tabular}{|l|cl|}
\hline Themes & \multicolumn{1}{|c|}{ Cluster Themes } \\
\hline 1. Prelude to CEO succession & $*$ & Sensing impending CEO succession \\
& $*$ & Preparation for CEO succession \\
& $*$ & Relationship with outgoing CEO \\
& $*$ & Understanding the reasons for CEO succession. \\
& $*$ & MM's participation in recruitment of a new CEO \\
\hline 2. Deeper encounters and & $*$ & Experiencing a new CEO- initial impressions of a new CEO \\
impacts: Experiences of actual & $*$ & MMs experiences of new CEO beyond initial interactions \\
CEO change & $*$ & Impact of the transition/interim period on MMs \\
& $*$ & MMs experience of CEO exit in parastatals \\
& $*$ & Experiencing a smooth, healthy CEO succession \\
& $*$ & Experiencing a difficult CEO succession \\
\hline 3. Emotional impact on MMs & $*$ & MMs emotions during CEO change \\
and practical responses & $*$ & MMs learnings/key lessons from a CEO succession \\
& $*$ & Coping strategies of MMs during CEO succession \\
\hline 4. Employment relations & $*$ & CEO succession and MMs supervisory role \\
during CEO succession & $*$ & MMs workload during CEO succession \\
& $*$ & CEO succession and performance \\
& $*$ & CEO change and impact across hierarchies \\
& $*$ & Career progression of MMs during CEO change \\
& $*$ & Limited or no impact of CEO change to MMs \\
& $*$ & CEO succession and impact on the family of the MM \\
& $*$ & Inter-staff relationships, wellbeing and CEO change. \\
& $*$ & Staff turnover, exit and job losses \\
\hline & &
\end{tabular}

Theme 1: Prelude to CEO Succession

This theme captures the pre-succession activities expressed in the clusters of sensing impending CEO succession, preparation for CEO succession, relationship with outgoing CEO, understanding reasons for CEO succession, and MM's participation in recruitment of a new CEO. MMs revealed that prior to a CEO change there were pointers. As one participant noted, "It was not a surprise. Because by the time it came, they had seen it coming, it was not all that a big shock" (30-11-B).

The signs of a coming CEO succession were a change of the governance body, declining performance, constrained finances, and staff turnover particularly at the top. The change of a governance body often led to agitation for a change of the CEO particularly if the sitting CEO had a long time tenure. The decline in performance coupled with constrained finances triggered CEO change even if there was no change of governing body. One MM observed,

"... when a management is put in place, they are given specific targets they are supposed to meet, the mandate was not fully achieved and that is what was based on to change this management" (30-11-B).

MMs connected conflicts within the boardroom to a looming CEO change. Such disagreements lead to a decline in performance, triggering a CEO succession. Participant 22-11-B stated, "We would hear there was a lot tension in the boardroom... a lot of quarrelling, as you would be passing the boardroom..." Apart from the board, the change in the political head of the parent ministry portended a CEO change. The other 
indicator of a CEO change was the behaviour of the CEO. A CEO planning to exit reduced engagement, profusely delegated, and halted major change processes.

\section{Preparation for CEO Succession}

Some of the MMs had sufficient preparation for the change while others had little. For the former, adequate preparation included early announcement of the change, and on-going communication from the sitting CEO about the impending exit. Uncertainty about the future of the organization, unanswered questions, and resistance to the new CEO were regular experiences of staff that went through a CEO succession without preparation. Comments from two participants illustrate the contrast between prepared $\mathrm{MM}$ and those who were not: "And we did not know why we were going to have a new Managing Director. I did not know myself" (10-11-A); "It was not just an abrupt event, it was a process... we saw it coming, we knew it" (10-11-B).

\section{Relationship With Out-Going CEO}

The impact a CEO change on a MM was influenced by the relationship s/he had with the outgoing CEO. MMs with a long tenure had more attachment to an outgoing CEO and found it harder to cope. They had been mentored by the outgoing CEO and attributed their career advancement to him/her. One participant with a long career in the PE shared thus, "Some changes may be good, or others may be bad. It depends on your relationship with who is leaving" (15-11-A).

\section{Understanding the Reasons for CEO Departure}

The reasons for CEO departure were concealed as one MM commented:

"We just got to know that he resigned. And when we were told we were shocked. To me I would feel like even if it is strategic issues... it would have been better for staff to get that information. But you couldn't be given that information" (22-11-B).

Letting the staff know the reasons for the CEO departure would have helped staff to prepare for the change.

\section{Participation in Recruitment of a New CEO}

The recruitment activities for the CEO alerted staff that a new leader was coming. The MMs involvement in the CEO selection ranged from minimal to none. They believed they could not affect the selection process and considered this a preserve of the board. One participant when asked the role she played responded, "I do not think that my influence goes that far" (09-11-B). Another exclaimed, "Not any I can remember. I did not have any input" (09-11-A). On hindsight, long serving MMs believed they should have participated in reviewing the job description, crafting interview questions, assessing applications, and orientating the new CEO. When MMs were excluded in the selection process, they questioned the criteria used, felt there was unfairness and doubted the competency of the new CEO.

\section{Theme 2: Deeper Encounters}

This theme covers experiences from the exit of a CEO to the arrival of a new one. The theme clusters are: Experiences of the CEO exit, initial impressions of a new CEO, experiences of new CEO beyond initial interactions, impact of the transition/interim period. Others are experiencing a smooth and difficult CEO successions.

Participants observed that some CEOs publicly communicated their intended exit to staff. As participant 16-11-B explained, "We just heard that the CEO has resigned. A few minutes after that rumor, he sent us his resignation letter". CEO's exit meetings were often emotional. A participant who had closely worked with an exiting CEO recalls, "It was very emotional because he was like ... somebody is leaving, going to another life" (30-11-A). A farewell party for the exiting CEO with official handover, and where all staff attended was praised as a good practice. When an exiting CEO positively handled the last moments in the organization, it had lasting positive impact on the employees. 


\section{Transition}

When the departure of a CEO was unplanned, the replacement was in most cases an interim CEO picked from within. This transition was a time of instability and uncertainty about the direction of the organization. Nearly, all the MMs who went through a transition, experienced slackness and low morale. The interim period was characterized by exit of some top managers leaving a gap in the authorization structure. The interim CEO was cautious, slow and non-committal in decision making. Where the temporary CEO was close to a dismissed CEO, they displayed a similar leadership style. An experienced MM (22-11-A) stated thus, "[the interim CEO] -This man never changed his attitude...the same reasons that affected the former CEO affected him". On a positive note, MMs reported an increased cohesion among staff during the transition, and profound learning for MMs who took on executive responsibilities, interacting with the board/other higher authorities. One participant excitedly summed it up, “. . a lot of learnings. First of all, handling and associating with higher authorities" (09-11-A).

\section{Initial Impressions of New CEO}

MMs considered the profile of a new CEO and pre-determined his/her suitability for the job. One MM commented, "We knew him; we had read about him online. He had led organizations and we felt this was the right man" (16-11-A). In another PE, the participant narrated, "We were very, very happy with the person they had appointed because she is a person of integrity". These impressions were tested with the reporting of the CEO. MMs were anxious to listen to the maiden address of the CEO, and built expectations basing on this. Concerning the initial impressions, one MM narrated, "There was hope, there was joy because we had come from, dictatorial kind of leadership and we were getting a gentleman who was very experienced" (10-11-B). MMs expected the new CEO to immediately share her expectation of the departments they head. However, long serving MMs and those that had experienced several CEO successions, listened to initial speeches of the new CEO with skepticism. They considered him/her naïve at the time. For example, the new CEO's responses were mostly based on optimism rather than knowledge of the entity. Following the initial impressions, the MMs studied the new CEO's priorities, management/communication style, and beliefs.

\section{Beyond Initial Interactions}

Participants described a health relationship with a new CEO based on how well she facilitated work processes. One participant commented about a new $\mathrm{CEO}$, "He is supportive. I need an approval, I get it. And when he is not able to approve, he tells you his mind" (09-11-A). When new CEOs was knowledgeable about the core business of the PE, MMs were inspired and became assertive. For example, when a construction PE got a CEO who was an architect, participant 16-11-C captured the mood, "People were excited because that CEO [new] ... was an architect by profession... because they knew this one would understand the projects from the technical bit of it". MMs regarded a CEO as effective if s/he introduced changes that impacted on the core purpose of the entity such as restoration of systems; expanding staffing; setting up novel technologies, and businesses expansion. On the other hand, there was frustration among the MMs in PEs where frequent CEO changes occurred, but successors did not understand the core business of the entity. Participant 10-11-A expressed such disappointment, "So, my expectations ... unless this person is going to be a person, who is knowledgeable about programming ... he is not moving this PE anywhere". Participants appreciated it when a new CEO introduced changes that positively affected staff welfare. A sense of self confidence, hope and purpose flourished in the organization when the new CEO empowered MMs to implement innovations and share technical expertise.

\section{A Smooth Succession}

Characteristics of a smooth CEO succession were outlined as planned, with minimal interruption to the work, allowing staff to go about their business normally. Other elements include conformance to the organization's laid out procedures, and transparency with accountability to top management and MMs. In smooth CEO successions, the board allowed the outgoing CEO to draw their own exit plan, including recruitment and orientation of a replacement. MMs recommended a stay of at least one month for the 
outgoing CEO when the incoming CEO reports. However, a smooth CEO succession within Ugandan PEs was seen as unique and novel by the board and state regulatory bodies. The transparent handover function at a large PE was described thus: "It was the first of its kind. It was unusual, and the feeling was... this can also happen" (15-11-A).

\section{Difficult CEO Transitions}

These were abruptly done, violently executed or frequently orchestrated. MMs in some of the PEs experienced instances where CEOs were pushed out, left unceremoniously, or abandoned office. In other cases, CEOs assumed office unannounced. In some PEs, the departure of a CEO and the arrival of another was likened to an action-packed movie. One participant put it this way:

But how he came in. Oh my God! You just needed, may be a video to describe it... what happened, our CEO then, had to go through a fence and the new CEO came in and that is how he came to be and announced as CEO (10-11-A).

Difficult CEO successions were more common in Uganda's PEs. Some PEs had never had a voluntary CEO exit since their inception. For such PEs the MMs described a CEO succession as a tough experience. MMs viewed frequent CEO successions as reactionary, dramatic and confusing. They made MMs doubt the viability of the company. During frequent CEO changes, it was difficult to implement strategic and operational plans. Abrupt dismissals triggered shock and chaos as there was no one to immediately give direction. The swift exit of a CEO led to a decline in staff morale, loss of hope, and a waning in work effectiveness. The key questions that arose were related to meaning [why all this?], direction [what next?] and job security [am I next?]. MMs during erratic CEO changes experienced speculations, uncertainty and demoralization. They developed metaphors such as: When a CEO hastily leaves the entity, it is like when a captain of a ship is incapacitated or dies.

\section{Theme 3: Emotional Impact and Coping Emotional Impact}

Participants experienced mixed emotions: eagerness and hope versus fear/anxiety, uncertainty; then sadness, feeling of loss versus happiness and joy. On one hand, change was viewed as inevitable but on the other hand there was loss of a relationship with the outgoing CEO. As one MM (11-11-B) tersely put it, "There is creation of hope as new guards take place. But normally there is also fear among the staff. This new leadership, what is it going to bring about?" Where the transition process was protracted, the announcement of a new CEO restored calmness and a feeling of "finally it has ended". The expectation was that a new CEO would deal with what the former CEOs had failed to handle. A hasty CEO exit triggered negative feelings and emotional disturbances among staff. The departure of an inspirational CEO after a short stint, left MMs hurting, and dampened their mood. The stronger the emotional attachment between the outgoing CEO and the staff, the longer it took for staff to heal. CEO termination created a somber mood with staff shocked into temporary inaction. In some instances, the initial response to the CEO's sudden departure was hopelessness, uncertainty about the future, doubt, coldness or apathy as expressed by a participant, "You would sense the feeling of, am I in the right place, is there hope? Is there a future for me in this thing? ... the coldness of, are we moving forward?" (16-11-A). Whenever the CEO succession was followed by restructuring, there was tension, mistrust and doubts between the new CEO and staff. MMs who lost out during the new CEO's restructuring, became demotivated and felt disempowered.

\section{Learnings From a CEO Succession}

Going through a CEO change made MMs appreciate the unpredictability of change and the lack of job security. They set up personal survival plans in case the employment ended. A participant who witnessed a long serving CEO being terminated during a board meeting, shared thus, "The lesson I learnt is that you should always be ready for any change... you should always have side income... (22-11-A)". The need to update one's skills and knowledge became clear. Taking up acting executive roles during the transition 
resulted in profound learning. A MM (09-11-A) who was an accountant during the CEO change shared, "It was a learning experience for me... lots of interactions especially with the board. A lot of learnings ... handling and associating with higher authorities". Some MMs who took on acting roles enhanced their professional growth, as it exposed them to higher responsibilities, and interactions with top leadership.

\section{Theme 4: Employment Relations Inter-Staff Relationships}

Overall, CEO succession increased unity among staff as they all sensed an uncertain future. They formed cliques to help them cope with the change. Participant 16-11-C remarked, "So, we try to work together, and you do not leave the other one behind. At least there is that sense of family". The MMs observed that some staff under them lost morale and underperformed as a result of CEO succession events. As supervisors, MMs responded to critical questions from the staff, explained the changes, built confidence, and prevented their teams from despairing. The MMs informally assessed the impact that the CEO succession process had on the staff under their supervision. They alerted management of the issues their teams were facing and conveyed messages from management to lower staff. In difficult CEO successions, the supervisory role of the MMs declined since they could not make demands in an environment when they were uncertainty of their jobs.

\section{Middle Managers' Workload}

Some changes by the new CEO increased financial resources and staff portfolio. This raised the workload of MMs in administrative functions. Participant 09-11-A who was in a financial role intimated, "The inflow of money... means more work. The staff numbers have increased, that means more work in terms of facilitation". CEO change also led to increased workload as the MMs did not want to be seen as failures before the new CEO.

\section{Staff Turnover Exit and Job Losses}

CEO succession stirred up images of job loss and instability, accelerating staff turnover particularly when the change was followed by restructuring. There was minimal turnover when staff had been prepared for the CEO change. There were instances where staff did not leave because of the PE retirement pecks. The staff turnover elicited feelings of guilt among some staff. A participant confessed, "I had like my mentor ... who was stopped [laid off] ... it affects you...you feel like you pushed your mentor out".

\section{Impact on the Family of the MMs}

MMs going through a CEO succession kept their families informed and readily sought support from them. There was fear in the family of the possibility of loss of a family income. When the CEO departure was attended by turmoil, it had a ripple effect into the family relationships of the MM. The family was a source of emotional support during a CEO change.

\section{DISCUSSION}

\section{Prelude to CEO Succession}

Pre-succession factors could be referred to as the "we could sense it was coming" moments. The participants identified such factors as a change of the governance body, change in political leadership, declining performance, constrained finances and staff turnover particularly at the top. These findings suggest it is possible to anticipate CEO succession by watching for such factors. This tallies with some of the findings of Giambatista et al. (2005), who identified pre-cursor factors to CEO succession under board related issues, firm performance status, leader characteristics, peculiar firm characteristics, and market related matters. Although the sampled PEs varied along the firm characteristics of age and size, participants did not identify these factors as affecting a CEO change. Giambatista et al. did not include change of the political leadership. This could be because they focused on for- profit entities. Kickert (2014) observed that the fundamental difference between public and private enterprises is the political context, which is very 
important to PEs. Dimopoulos and Wagner's (2016) analysis of 812 CEO departures of the period 19952005 in UK and German concluded that CEO turnover was preceded by significant underperformance and this tallies with the findings of the current study.

In preparing of the staff for the CEO change, PEs differed. Two PEs did extensive preparations because their successions were smooth. In some of the PEs, the advantages of preparing staff for the CEO change were overridden by the political contingencies. Volpin (2008) noted that in state-controlled companies, the CEO of a poorly performing entity may not be removed from office until perceived political costs necessitate it, while the CEO of an effectively performing PE may not continue in office unless there are political benefits.

Another prelude to CEO succession was the engagement of outgoing CEO by the MMs. The impact a CEO change had on a MM was linked to the relationship s/he had with the outgoing CEO. Shapiro, Hom, Shen and Agarwal (2016) argued that "a leader's departure from the organization increases a subordinate's concern and associated appraisal regarding how well she or he will fare in the organization without that leader" (p.484). In this study the focus was on MM and CEO relationship. Where the CEO was autocratic, the exit brought relief among the MMs. Tepper (2000) explained that though the departure of a CEO might begin with some concerns, it can end with optimism if the leader was abusive and there is hope, the replacement will be better.

Under prelude to CEO succession, understanding the reasons for CEO departure was a recurring issue. Official communication was rarely provided. This secretive approach is sometimes done to save face of the exiting CEO and avoid post-CEO succession litigation. The participants in this study emphasized the need for transparency on the reasons for departure. According to Herzig and Jimmieson (2006), when MMs are aware of the reasons for change, their uncertainty is reduced. Serra and Borzillo (2013) in their study of 15 first-time successions among young companies in the Silicon Valley observed that when a founder CEO has a clear case for leaving, the members support the succession. Remarkably, none of the MMs in the research could show that they asked for the reasons for CEO departure. The MMs wanted to know the reasons for CEO departure but felt it would be disrespectful to question the TMT and the board. This could be associated with the vertical-collectivist culture in Uganda, with unquestioning respect for authority (House et al., 2004).

In the prelude to CEO change MMs followed the recruitment processes. This mentally prepared them for the incoming CEO. The tracing of recruitment events affected the way the MMs received the new CEO. For example, in the same PE one MM was very happy with the choice of the new CEO while another said that was not the CEO she was expecting! Both had been following the CEO recruitment process. Generally, CEO recruitment and selection are regarded as the preserve of the board and hence MMs and other employees provide little or no input (Bowen, 2008; Campbell, 2015).

\section{Deeper Encounters}

When the exits of CEOs were officially communicated to all staff and the exiting CEO invited the MMs to contribute to the handover report, the negative impact of CEO departure was toned down. Abrupt dismissals left trauma, which took long to heal as the staff were not allowed to "mourn' the departure of the CEO. Bridges (1986) delineated three phases of transition noting that people during the ending phase of change exhibit emotions and behaviours typical of mourning such as denial, anger, bargaining, grief and despair. Relatedly, Decker and Belohlav (1997) noted that this phase can be characterized by disbelief, denial, anger and sadness. Although these studies are not in direct reference to CEO succession, they resonate with it since $\mathrm{CEO}$ succession is a typical organizational change.

Some of the PEs witnessed a period of transition; when one CEO left and a substantive one had not yet come. Whenever a CEO abruptly left, a member of top management was elevated by the board to act. This is because boards had not invested in developing a leadership pipeline and had no succession plan. The appointment of an insider CEO is in consonance with the findings of Mooney, Semadeni and Kesner (2014). They analyzed a sample of 375 CEO successions in the USA listed companies between 1998 and 2005 and found that the board of directors was more inclined to select an interim CEO when the CEO was forced out, and there was no one groomed as heir apparent. The current study revealed that the interim period was 
a time of instability, and uncertainty about the direction the organization was taking. Ballinger and Marcel (2010) similarly observed that interim CEO succession introduces ambiguity and escalates the uncertainty of an already disruptive event. Mooney, Semadeni and Kesner (2014) had opined that in the absence of a permanent leader, there is no clear decision-making center, and politicization and fragmentation occasioned by temporary leadership may be heightened within top management. In the current study, nearly, all the MMs who experienced interim CEOs, reported slackness and low morale among staff. The interim CEO was cautious, slow and non-committal in decision making. Mooney, Semadeni and Kesner (2014) noted that the interim leader delays strategic direction and simply keeps the seat warm for the substantive CEO. The findings of the study indicate that appointment of an insider interim CEO evoked mixed reactions among MMs depending on the relationship they had with her/him at the time. Where the relationship was not cordial before, the MMs avoided close interactions, preferring instructions passed along the organizational hierarchy. During the transition, MMs reported increased cohesion among staff. This can be linked to a national culture predicated on collectivism and humane orientation depicting elements of care, and concern for one another (April, 2010; House, 2004).

In preparation for the arrival of the new CEO, MMs considered the profile of a new CEO. They used the CEO's maiden speech and accompanying actions to judge his/her capability. Thus a new CEO's first speech should be inspiring, intentional, and stress strategic direction. As Porter, Lorsch, and Nohria (2004) noted "a new CEO's words however off-the-cuff are instantly spread, amplified and sometimes misunderstood" (p.7). However, long serving MMs who had experienced several CEO successions, listened to maiden speeches of CEOs with skepticism. Thus, new CEOs should segment their audience and address concerns of long serving MMs. Given that a CEO change disrupts organizational processes, leading to uncertainty and instability, a new CEO's initial role is restoration of self-confidence, and trust in the team and institution. CEOs who immediately introduced drastic changes such as re-structuring caused further damage. In resource constrained PEs, it was hoped that a new CEO would increase resource flow to the entity. Where this did not occur, MMs and other staff were frustrated. Some of the MMs referred to a "changeless change" when the change in CEO lead to insignificant changes. This is what in change management is called organizational change cynicism (OCC). Barton and Ambrosini (2013) in their research on middle managers from 701 'high tech' organizations in the UK demonstrated that senior management support, information availability and procedure justice were significantly and negatively related to OCC. In the current study, some MMs were not officially informed about the CEO succession, and others felt the procedures for exiting the CEO were unfair. This could have heightened the OCC. This tallies with the scapegoating theory of CEO succession wherein it is considered irrational to attribute either a positive or negative performance to a succession event, given the time it takes for organizational members to make sense of the change (Gamson \& Scotch, 1964; Rowe et al., 2005).

\section{Experiences Beyond Initial Interactions}

New CEOs introduced changes that impacted on the core purpose of the entity. Such a CEO was viewed as not one who has come to run the "business as usual" but one who has brought a fundamental change. This affirms scholarly findings that new CEO with their fresh perspectives are more likely to initiate changes (Weng \& Lin, 2014). Thus, a new CEO should aim at introducing positive change at the earliest possible time.

The MMs got back to work faster when the new CEO developed effective communication, galvanizing the entire organization to implement the changes. This period coincides with what Decker and Belohlav (1997) described as the initiating phase, wherein people embrace the new reality and new relationships, understand the reasons for change, and are committed to it. A sense of self confidence, hope and purpose flourished when the new CEO empowered MMs through allowing them to originate and implement innovations and giving them an opportunity to share their technical expertise. Mbigi (2002) described the African leadership model as placing purposeful emphasis on people and their dignity, which tallies up with the current finding. 
Another finding was that MMs felt that a new CEO was oblivious of their past work and had to work harder to win his or her trust. Their position 'in the middle' forces them to develop new skills to improve their chances of survival during the ongoing change (Embertson, 2006; Hogg \& Terry, 2000; Huy, 2016).

MMs felt that they were allowed minimal participation by the new CEO when a strategic plan was under fomentation. The MMs are power wielders and when left out, frustrate implementation of plans. Similar findings are attested to by Floyd and Wooldridge (1997) who viewed the MM from a functional aspect as "the coordinator between daily activities of the units and the strategic activities of the hierarchy" (p. 48). Darkow (2013) rightly observed that the expertise to develop a strategy called for detailed knowledge and capabilities, which can be found in middle management.

In some of the PEs when members of top management exited following a CEO change, they left a vacuum which was filled by MMs, mostly in acting capacity. This is affirmed by other researchers who found that many surviving MMs acquired a greater strategic role as the result of organizational change (Dopson \& Stewart, 1990; Frohman \& Johnson, 1993, Ma \& Seidl, 2018).

\section{Experiencing a Smooth CEO Succession}

A smooth CEO succession process within PEs was described as extra-ordinary, and novel by the board and state supervisory body. This finding may allude to the fact that PEs in Uganda rarely plan for CEO succession. Rivolta (2018) has suggested that a lack of CEO succession planning is disruptive and increases business risk. MMs recommended a longer interface between the incoming and outgoing CEO suggesting it provides mentoring and passing on of organizational memory to the new CEO. Similar observations were made by Rivolta (2018) about planned CEO exits having the advantage of the incumbent CEO participating in the recruitment and grooming of his/her successor.

\section{Difficult CEO Transitions}

The emotional hurt staff undergo in difficult CEO changes needs to be recognized and addressed by the incoming management, otherwise staff live with it. Kickert (2014) summarized the mood of staff undergoing frequent changes thus, "The umpteenth organizational change at the umpteenth change of the top does not make people happy" (p. 700). Deprez (2017) commenting on emergency CEO change in family succession businesses noted that, "The successor CEO needs to immediately address the emotions and give the employees permission to grieve the loss" (p. 1).

\section{Emotional Impact and Coping}

The mixed emotions narrated by the MMs meant they could not delineate the dominant emotions. Bridges' (1986) transition model of change classifies this period of confusion as the neutral zone of change engendering uncertainty, loss, and confusion. It is a time of growing hope and intermittent sense of despair; new ideas alternating with moments of meaninglessness. Other researchers have alluded to emotional complexities arising from multiple interpretations of the emergent situation during CEO change (Manzoor, Johnson \& Rashid, 2018).

The key positive emotions were of joy and hope. Similar findings were made by Ngotngamwong (2014) in a qualitative study that investigated the perception of employees on the impact of leadership change in Thailand. The study concluded that employees developed professionally, became more confident, and were well placed to make better decisions; all of which point to positive energy.

On the negative side, the study showed that abrupt CEO exit created a sombre mood and staff were shocked into temporary inaction. Ngotngamwong (2014) found that a section of employees undergoing frequent leadership change, experienced stress, tension, fatalism, and demotivation.

\section{Learnings From a CEO Succession}

All participants going through a CEO change were forced to re-consider their job security. PEs in Uganda have for long been bastions of employment for life. But when MMs witnessed a difficult CEO change, they began to consider updating their knowledge and skills for employability elsewhere, should they exit their roles. 


\section{MM's Coping Strategies}

MMs with a long tenure had more attachment to an outgoing CEO and found it harder to cope. Conversely, staff with no close ties adapted faster. This view is shared by Shapiro and Agarwal (2016) who concluded that "when employees lose leaders with whom they have had good relationships, their sense of loss will be greater, and this may weaken their desire to stay with their organization" (p. 480). The $17 \mathrm{MMs}$ who survived the CEO succession embraced the change. They worked as teams, increased networking and formed cliques. This can be explained by a collectivist African culture with a tight social network and strong cohesive in-groups (House et al., 2004). This is further echoed by the African leadership philosophy of Ubuntu wherein collective personhood and collective morality are emphasized (Van derColff, 2003).

\section{Employment Relations}

Participants recalled that $\mathrm{CEO}$ change in some cases temporarily led to rifts but due to long tenure ties, the staff got together again. Thus, a new CEO can ride on this bonding by spearheading teambuilding activities. In some PEs such activities were used in handling employee relations while in others, they were learning forums. The temporary rifts were expected given that CEO succession is a time of tension, confusion and disruption (Ballinger \& Marcel, 2010). Balser and Carmin (2009) who studied CEO succession process of a non-profit found that succession can affect organization identity. This leads to some employees responding with resistance, conflict or forming factions.

Regarding supervision, MMs played a transactional role, helping the lower staff accept change and top management understand the impact of change on lower staff. A similar observation was made by Harding, Lee and Ford (2014) who noted the pivotal role MMs played between the executive and employees. Findings elsewhere indicate that empowering MMs is the key to effective change implementation (Kuyvenhoven \& Buss, 2011) and the converse holds true

In this study, the MM's family was found to be a source of emotional support and was concerned about the possible job loss. Gordon (2002) asserted that African leadership is deeply rooted in African cosmology and world views, the major elements of which include religion, family, kinsmanship and tribalism. Thus, within a Ugandan setting, the family played a critical role as the MMs experienced a leadership change. This finding challenges the notion of an ideal worker, expected to separate the work and the family roles (Rapoport et al., 2002).

Growth in staff numbers is often viewed as a positive organizational index, but in the study, it increased workload for those in administrative functions. There is a need to analyze staffing levels within administrative functions, whenever staff and financial resources of PEs grow. However, the increased workload had positive outcomes for MMs including seeking for skills enhancement opportunities and becoming more consultative. Iida and Morris (2008) observed that MMs during a change process undertook a greater range of tasks.

CEO succession negatively impacted on the careers of the MM when it was immediately followed by re-structuring. Such CEO succession signaled an end to the career path, stirring up images of job losses, and staff turnover. MMs who survive downsizing, analyze how organizational changes impact on their professional development and future careers, and are often left demoralized (Becker, 1997; Reissner, 2010; Svenigsson and Alvesson 2003). The MMs interviewed were cagy about those who left; it was a sensitive matter. Only one interviewee mentioned it, almost with trepidation:

I had like my mentor .... one of the people who was stopped and obviously, it affects you. On a personal basis, it was really difficult for me. Because it took me like a month to call and find out how they were doing (16-11-C).

This is reflective of the African culture of collectivism and Ubuntu leadership philosophy. In collectivist cultures everyone tends to look out for others within their community of reference (House et al., 2004). Ubuntu promotes the humanity, dignity of others, collective solidarity, social justice and equality of each human being (Khoza, 2006; Van derColff, 2003). 
But CEO change and restructuring can also result in positive outcome wherein a MM ascends the career ladder. This was the confession of some of the MMs who were interviewed for this study. Some MMs observed that CEO change increased staff readiness for other changes if combined with restructuring brought in new people, contributing to improved performance. This rhymes with the common-sense theory of CEO change wherein a change in leadership boosts performance (Boyne, James, John, \& Petrovsky, 2011; Karg, McDonald \& Schoenberg, 2015; Dimopoulos \& Wagner, 2016)

Alternatively, performance during CEO change was negatively affected in some PEs. Frequent CEO changes led to organizational instability and poor performance. This is sympathetic to Grusky's (1963) vicious cycle theory where CEO change leads to poor performance; the new CEO is dismissed, creating a spiral of CEO changes without improving performance.

\section{CONCLUSIONS AND RECOMMENDATIONS}

The study answered the research question and contributed to the study of CEO succession, particularly in Uganda. It addressed the five sub-questions and thus the main research question, using descriptions patterned along the four themes with selected quotes from the transcripts of MMs. The MMs pointed out emotional issues: loss of morale, sadness/sombre mood, doubt, fear and uncertainty, excitement and emergence of hope. Themes 2-4 described what happens internally in the organization during a CEO succession.

\section{Contribution of the Research and Theoretical Implications of the Findings}

The study addressed the unexplored area of the experiences of MMs during a CEO succession, offering scholars another dimension of what happens during a CEO change. It thus adds to the CEO succession literature by answering the question, "what happens to employees below the TMT hierarchy in a CEO succession? Additionally, the study augments the emerging scholarly work in the area of CEO succession in Africa. It challenges the existing research orientation wherein there is a copious flow of papers focusing on the listed companies. There is a different dynamic during CEO succession in a PE compared to a listed company.

The thematic map and fundamental structure for the CEO succession experiences of MMs generated by the study can act as frameworks for the design of future research in CEO succession and MMs in PEs.

\section{Practical Implications for Leadership and CEO Succession}

The study has created a thematic map and a fundamental structure for the CEO succession experiences of MMs to which the board and TMT can turn to when planning a CEO succession in regard to MMs. The study revealed signs that portended a CEO change. MMs recognizing such precursors can prepare better for CEO change. The findings indicate that MMs who went through a smooth CEO succession were motivated, engaged and committed to the organization. Thus, boards of PEs have a responsibility of ensuring that there is a succession plan and promote a smooth CEO succession. Given the findings relating to emotions, relationships, coping mechanism and preferences of MMs, the board, government and top management ought to involve MMs in key processes of CEO succession. The findings also task the new $\mathrm{CEO}$ to understand and immediately address the emotions of MMs.

Findings indicated that in difficult CEO transitions, the supervisory role of the MMs declined. Governance bodies of PEs need to consider the impact difficult CEO changes have on performance of the entities.

\section{Study Limitations}

One limitation of the study was the small purposively selected sample (17 participants). However, in phenomenological studies, there is no universally accepted sample size. A related limitation was the inability to generalize findings. But being a phenomenological research, generalizing the findings was not the aim. The findings though, may be transferable. 
Data was mainly collected through in-depth interviewing, which relies on the ability to recall the experiences. Participants were selected from PEs that had a CEO change within the last 30 months, which was considered a short lapse to recall events. But whatever implication this might posit in terms of the findings' credibility is hopefully mitigated by returning transcripts and the fundamental structure to participants for validation.

Because of the subjective nature of qualitative research, the results could be biased. Bracketing was utilized to limit such personal bias, though the study cannot claim ideal bracketing was done. Phenomenologists themselves have argued about the practicality of a perfect bracketing (Giorgi, 2011; LeVasseur, 2003).

\section{Areas for Further Research}

It is likely that with a different qualitative data analysis approach, the phenomenon will emerge with new descriptors or thematic maps. For example, instead of Colaizzi (1978), researchers could analyze the data using Hycner's (1985) or Moustakas' (1994) approaches. Such triangulation could yield comparisons and contrasts in the results generated. MMs that went through a CEO succession but quit during the process were not interviewed. Including them as participants or even focusing on them alone may enrich future findings.

\section{REFERENCES}

Adam, J. (2014). Trust loss in Tanzanian parastatal organisations: Causes and consequences to the governance mechanisms. Contemporary Journal of African Studies, 2(2), 33-63.

Adewale, O.O., Abolaji, A.J., \& Kolade, O.J. (2011). Succession planning and organizational survival: Empirical study on Nigerian private tertiary institutions. Serbian Journal of Management, 6(2), 231-246.

Adler, S.E., Berry, M.J., \& Doherty, D. (2013). Pushing "reset": The conditional effects of coaching replacements on college football performance. Social Science Quarterly, 94(1), 1-28.

April, K. (2010). Four step processes to implement African leadership: An empirical evaluation. Retrieved from https://www.ashridge.org.uk/MediaLibrary/Ashridge/PDFs/Publications/FourStepProcessToImplementAfricanLeadership.pdf

Ballinger, G.A., \& Marcel, J.J. (2010). The use of an interim CEO during succession episodes and firm performance. Strategic Management Journal, 31(3), 262-283.

Ballinger, G.A., \& Schoorman, F.D. (2007). Individual reaction to leadership succession in workgroups. Academy of Management Review, 32(1), 118-136.

Balogun, J., \& Johnson, G. (2004). Organizational restructuring and middle managers sense making. Academy of Management Journal, 47(4), 523-549.

Balser, D.B., \& Carmin, J. (2009). Leadership succession and the emergence of an organizational identity threat. Nonprofit Management \& Leadership, 20(2), 185-201.

Barton, L.C., \& Ambrosini, V. (2013). The moderating effect of organizational change cynicism on middle manager strategy commitment. The International Journal of Human Resource Management, 24(4), 721-746.

Becker, G.S. (2008). Human capital: The concise encyclopedia of economics. Library of Economics and Liberty. Retrieved from http://www.econlib.org/library/Enc/HumanCapital.html

Boeker, W. (1992). Power and managerial dismissal: Scapegoating at the top. Administrative Science Quarterly, 37(3), 400-421.

Boeker, W. (1997). Strategic change: The influence of managerial characteristics on organizational growth. Academy of Management Journal, 40(1), 152-170.

Bowen, G. (2008). The board book: An insider's guide for the directors and trustees. New York, NY: W.W. Norton \& Company. 
Boyne, G.A., James, O., John, P., \& Petrovsky, N. (2011). Leadership succession and organizational success: When do new chief executives make a difference? Public Money \& Management, 31(5), 339-346. doi:10.1080/09540962.2011.598345

Bridges, W. (1986). Managing organizational transitions. Organizational Dynamics, 15(1), 24-33. http://dx.doi.org/10.1016/0090-2616(86)90023-9

Brown, C.M. (1982). Administrative succession and organizational performance: The succession effect. Administrative Science Quarterly, 27(1), 1-16.

Bruton, G.D., Peng, M.W., Ahlstrom, D., Stan, C., \& Xu, K. (2015). State-owned enterprises around the world as hybrid organizations. The Academy of Management Perspectives, 29(1), 92-114. http://dx.doi.org/10.5465/amp.2013.0069

Campbell, G., \& Boyden, P. (2015). Actively developing future CEOs: Boards need to ensure it happens. Governance Directions, 67(4), 213-216.

Chaganti, R., \& Sambharya, R. (1987). Strategic orientation and characteristics of upper management. Strategic Management Journal, 8(4), 393-401.

Charan, R. (2005). Ending the CEO succession crisis. Harvard Business Review, 83(2), 4-13.

Cohen, M.Z., Kahn, D.L., \& Steeves, D.L. (2000). Hermeneutic phenomenological research: A practical guide for nurse researchers. Thousand Oaks, CA: Sage.

Colaizzi, P.F. (1978). Psychological research as the phenomenologist views it. In R. Vaile \& M. King (Eds.), Existential phenomenological alternatives for psychology (pp. 48-71).

Conway, E., \& Monks, K. (2011). Change from below: The role of middle managers in mediating paradoxical change. Human Resource Management Journal, 2l(2), 190-203. doi: 10.1111/j.17488583.2010.00135.x

Costa, L.P.M.P. (2013). Portuguese stock market reaction to CEO turnover announcements (Unpublished master's thesis). Universidade do Porto, Porto.

Creswell, J.W. (2006). Qualitative inquiry and research design: Choosing among five approaches. Thousand Oaks, CA: Sage Publications.

Darkow, I.L. (2013). The involvement of middle management in strategy development: Development and implementation of a foresight-based approach. Technological Forecasting \& Social Change, 101, $10-24$.

Dauda, A. (2009). Business continuity and challenge of succession in Nigeria: What happens when the CEO leaves? Journal of Business and Management, 8(4), 59-65.

Davidson, W.N., Worrell, D.L., \& Dutia, D. (1993). The stock market effects of CEO succession in bankrupt firms. Journal of Management, 19(3), 517-533.

Dawley, D., Hoffman, J.H., \& Smith, A.R. (2004). Leader succession: Does gender matter? Leadership \& Organization Development Journal, 25(8), 678-690. doi:http://dx.doi.org/1108/01437730410565004

Decker, D.C., \& Belohlav, J.A. (1997). Managing Transitions. Quality Progress, 30(4), 93-96.

Deprez, B. (2017). Successor CEO Leadership during an unexpected or emergency Succession. Retrieved from http://www.deprezleadership.com/successor-ceo-leadership-during-an-unexpected-oremergency-succession/

Dimopoulos, T., \& Wagner, H.F. (2016). Corporate governance and CEO turnover Decisions. Swiss Finance Institute Research Paper No. 12-16. http://dx.doi.org/10.2139/ssrn.2040690

Dopson, S., \& Stewart, R. (1990). What is happening to middle management? British Journal of Management, 1(1), 9-13.

Embertson, M.K. (2006). The importance of middle managers in healthcare organizations. Journal of Healthcare Management, 51(4), 223-232.

Finkelstein, S., \& Hambrick, D.C. (1996). Strategic leadership: Top executives and their effects on organizations. Academy of Management Review, 22(3), 802-805.

Floyd, S.W., \& Wooldridge, B. (1994) Dinosaurs or dynamos? Recognizing middle management's strategic role. Academy of Management Executive, 8(4), 47-56. 
Floyd, S.W., \& Wooldridge, B. (1997). Middle management's strategic influence and organizational performance. Journal of Management Studies, 34(3), 465-485.

Froese, F.J., \& Bebenroth, R. (2012). Performance outcome of leadership succession at foreign subsidiaries in Japan: Does nationality matter? Discussion paper series /Research Institute for Economics and Business Administration, Kobe University.

Frohman, A.L., \& Johnson, L.W. (1993). The middle management challenge: Moving from crisis to empowerment. New York, NY: McGraw-Hill

Gamson, W.A., \& Scotch, N.A. (1964). Scapegoating in baseball. American Journal of Sociology, 70(1), 69-72.

Giambatista R.C., Rowe, W.G., \& Riaz, S. (2005). Nothing succeeds like success: A critical review of succession literature since 1994. The Leadership Quarterly, 16(6), 963-991.

Giorgi, A. (1994). A phenomenological perspective on certain qualitative research methods. Journal of Phenomenological Psychology, 25(2), 190-220.

Gordon, J.U. (2002). African leadership in the twentieth century: An enduring in democracy. New York: University Press of America.

Grusky, O. (1961). Corporate size, bureaucratization, and managerial succession. American Journal of Sociology, 67(3), 263-269.

Grusky, O. (1963). Managerial succession and organizational effectiveness. American Journal of Sociology, 69(1), 21-31.

Harding, N., Lee, H., \& Ford, J. (2014). Who is "the middle manager"? Human Relations, 67(10), 1213 1237. doi:10.1177/0018726713516654

Haveman, H.A. (1993). Ghosts of managers past: Managerial succession and organizational mortality. Academy of Management Journal, 36(4), 864-881.

Haveman, H.A., Russo, M.V., \& Meyer, A.D (2001). Organizational environments in flux: The impact of regulatory punctuation on organizational domains, CEO succession and performance. Organization Science, 12(3), 253-273.

Herzig, S.E., \& Jimmieson, N.L. (2006). Middle managers' uncertainty management during organizational change. Leadership \& Organization Development Journal, 27(8), 628-645.

Hogg, M.A., \& Terry, D.J. (2000). Social identity and self-categorization processes in organizational contexts. Academy of Management Review, 25(1), 121-140. doi:10.2307/259266.

House, R.J., Hanges, P.J., Javidan, M., Dorfman, P., \& Gupta, V. (2004). Culture, leadership, and organizations: The GLOBE study of 62 societies. Thousand Oaks, CA: Sage Publications.

Hutzschenreuter, T., Kleindienst, I., \& Greger, C. (2012). How new leaders affect strategic change following a succession event: A critical review of the literature. The Leadership Quarterly, 23(5), 729-755.

Huy, Q. (2016). Middle managers will rise in value. Retrieved from https://knowledge.insead.edu/sites/all/themes/knowledge2015/img/share-more-button.png

Hycner, R.H. (1985). Some guidelines for the phenomenological analysis of interview data. Human Studies, 8(3), 279-303.

Iida, T., \& Morris, J. (2008). Farewell to the salaryman? The changing roles and work of middle managers in Japan. International Journal of Human Resource Management, 19(6), 1072-1087.

Intintoli, V.J. (2013). The effects of succession choice surrounding CEO turnover announcement: Evidence from marathon succession. Financial Management, 42(1), 211-238.

Jackson, T. (2002). The management of people across cultures: Valuing people differently. Human Resource Management, 4l(4), 455-475.

Jackson, T., Amaeshi, K., \& Yavuz, S. (2008). Untangling African indigenous management: Multiple influences on the success of SMEs in Kenya. Journal of World Business, 43(4), 400-416.

Jauch, L.R., Osborne, R.N., Gleuck, W.F. (1980). Short-term financial success in large business organizations: The environment-strategy connection. Strategic Management Journal, 1(1), 49-63.

90 Journal of Leadership Accountability and Ethics Vol. 18(2) 2021 
Johnson, M., \& Härtel, C. (2014, October). Engaging middle managers for positive organizational change- Discussion Paper. Australian Institute of Management Research. Retrieved from https://www.aim.com.au/sites/default/files/downloads/MIddleManagersDiscussionPaper2014.pdf

Kabiru, F.C., Theuri, M.M., \& Misiko, A.J. (2018). The influence of leading on the organizational performance of agricultural state owned corporations in Kenya. International Academic Journal of Innovation, Leadership and Entrepreneurship, 2(2), 1-16.

Kanyeihamba, G.W. (2012, October). A country's dream: Uganda through 14 constitutions. Daily Monitor- A Uganda at 50 Magazine, pp. 150-151.

Karg, A., McDonald, H., \& Schoenberg, G. (2015). The immediate impact of coach succession events on season ticket holder attitudes. Sport Marketing Quarterly, 24(1), 30-42.

Kauzya, J. (2008). Uganda country study. In J. Coorkery, C.O. Nuallain, \& R. Wettenhall, (Eds.), Public enterprises boards: What they are and what they do: Reports from an international study (pp. 156-166). Brussels, Belgium: International Association of Schools and Institutes of Administration.

Kesner, I.P., \& Dalton, D.R. (1994). Top management turnover and CEO succession: An investigation of the effects of turnover on performance. Journal of Management Studies, 31(5), 701-703.

Kesner, I.P., \& Sebora, T.C. (1994). Executive succession: Past, present and future. Journal of Management, 20(2), 327-372.

Khoza, R. (2006). Let Africa lead: African transformational leadership for 21 st century business. Johannesburg, South Africa: Vezubuntu.

Kickert, W.J.M. (2014). Specificity of change management in public organizations: Conditions for successful organizational change in Dutch ministerial departments. American Review of Public Administration, 44(6), 693-717.

Klenke, K. (2008). Qualitative research in the study of leadership. Bingley, England: Emerald Group Publishing Limited.

Kuada, J. (2010). Culture and leadership in Africa: a conceptual model and research agenda. African Journal of Economic and Management Studies, 1(1), 9-24.

Kuyvenhoven, R., \& Buss, W.C. (2011). A normative view of the role of middle management in the Implementation of strategic change. Journal of Management and Marketing Research, 8, 1-15.

LeCounte, J.F., Prieto, L.C., \& Phipps, S.T. (2017). CEO succession planning and organizational performance: A human capital theory approach. Journal of Leadership, Accountability and Ethics, 14(1), 46-57.

LeVasseur, J.J. (2003). The problem of bracketing in phenomenology. Qualitative Health Research, 13(3), 408-420.

Lockmer, A. (2014). Outsider CEOs: The Impact on Firm Performance and Employee Commitment. Seminar Research Paper, Series. Paper 26. Retrieved from http://digitalcommons.uri.edu/lrc_paper_series/26

Ma, S., \& Seidl, D. (2018). New CEOs and their collaborators: Divergence and convergence between the strategic leadership constellation and the top management team. Strategic Management Journal, 39(3), 606-638.

Manzoor, H., Johnson, N., \& Rashid, M.U. (2018). Emotions during executive succession in a public board. Journal of Organizational Change Management, 31(3), 766-776.

Maphosa, F. (1999). Leadership succession: A recalcitrant problem in the indigenisation of African economies. Zambezia, 26(2), 169-182.

Masango, M. (2002). Leadership in the African context. Verbum et Ecclesia, 23(3), 707-718.

Mbigi, L. (2002). Spirit of African leadership: A comparative African perspective. Journal for Convergence, 3(4), 18-23.

McConville, T., \& Holden, L. (1999). The filling in the sandwich: HRM and middle managers in the health sector. Personnel Review, 28(5/6), 406-424.

Mooney, C.H., Semadeni, M., \& Kesner, I.F. (2014). The selection of an interim CEO: Boundary conditions and the pursuit of temporary leadership. Journal of Management, 20(10), 1-21. 
Moustakas, C. (1994). Phenomenological research methods. Thousand Oaks, CA: Sage Publications. New York, NY: Oxford University Press.

Ngotngamwong, R. (2014). Impacts of frequent leadership changes as perceived by employees. Journal of Management, 12(1), 51-62.

Ojeka, S.A., Adetula, D.T., Mukoro, D.O., \& Kpokpo, O.P. (2017). Does chief executive officer succession affect firms' financial performance in Nigeria? International Journal of Economics and Financial Issues, 7(2), 530-535.

Patton, M.Q. (2002). Qualitative research \& evaluation methods. Thousand Oaks, CA: Sage Publications.

Porter, M.E., Lorsch, J.W., \& Nohria, N. (2004). Seven surprises for new CEOs. Harvard Business Review, 82(10), 62-75.

Reissner, S.C. (2010). Change, meaning and identity at the workplace. Journal of Organizational Change Management, 23(3), 287-299. https://doi.org/10.1108/09534811011049617

Rivolta, M.L. (2018). Does lead time in CEO succession matter? Evidence from planned versus unexpected CEO departures. International Journal of Financial Research, 9(3), 1-19.

Rowe, W.G., Cannella, A.A., Jr., Rankin, D., \& Gorman, D. (2005). Leader succession and organizational performance: Integrating the common-sense, ritual scapegoating, and vicious-circle succession theories. The Leadership Quarterly, 16(2), 197-219.

Russell, R.A. (2014). CEO succession planning: A framework for boards. Retrieved from http://www.russellreynolds.com/insights/thought-leadership/ceo-succession-planning-aframework-for-boards

Sakano, T., \& Lewin, A.Y. (1999). Impact of CEO succession in Japanese companies: A co-evolutionary perspective. Organization Science, 10(5), 654-671.

Santora, J.C., Clemens, R.A., \& Sarros, J.C. (1997). Views from the top: Foundation CEOs look at leadership succession. Leadership \& Organization Development Journal, 18(2), 106-113.

Schwendinger, B. (2011). A methodology to explore family business succession. International Journal of Management Cases, 8(4), 34-41.

Serra, C.K., \& Borzillo, S. (2013). Founder succession in new ventures: The new human perspective. Journal of Business Strategy, 34(5), 12-24.

Shapiro, D.L., Hom, P., Shen, W., \& Agarwal, R. (2016). How do leader departures affect subordinates' organizational attachment? A 360-degree relational perspective. Academy of Management Review, 41(3), 479-502. doi:10.5465/amr.2014.0233.

Soebbing, B.P., \& Washington, M. (2011). Leadership succession and organizational performance: Football coaches and organizational issues. Journal of Sport Management, 25(6), 550-561.

Svenigsson, S., \& Alvesson, M. (2003). Managing managerial identities: Organizational fragmentation, discourse and identity struggle. Human Relations, 56(10), 1163-1193.

Swanson-Kaufmann, K.M., \& Schonwald, E. (1988). Phenomenology. In B. Sarter (Ed.), Path to knowledge: Innovative research methods for nursing (pp. 97-105). New York, NY: National League for Nursing.

Swider, B.W., \& Li, N. (2013, August). Demystifying the impact of leader succession: An integration of three divergent theories. Paper presented at the 73rd Annual National Meeting of Academy of Management, Orlando, FL.

Tepper, B.J. (2000). Consequences of abusive supervision. The Academy of Management Journal, 43(2), 178-190. doi: $10.2307 / 1556375$

Timbe, M.W., \& Sira, F.N. (2013). Challenges facing succession management in the Kenyan Civil Service: A case study of Nairobi County in the Ministry of Education. International Journal of Enhanced Research in Management \& Computer Applications, 2(8), 18-23.

Vakola, M., \& Nikolaou, I. (2005). Attitudes towards organizational change. What is the role of employees' stress and commitment? Employee Relations, 27(2), 160-174.

Van der Coff, L. (2003). Leadership lessons from the African tree. Management Decision, 41(3), 257261. 
Volpin, P.F. (2008). Governance with poor investor protection: Evidence from top executive turnover in Italy. In R.A.I. Van Frederikslust, J.S. Ang, \& P.S. Sudarsanam (Eds.), Corporate governance and corporate finance: A European perspective (pp. 257-284). New York, NY: Routledge.

Weng, D.H., \& Lin, Z. (2014). Beyond CEO tenure: The effect of CEO newness on strategic changes. Journal of Management, 40(7), 2009-2032.

Wooldridge, B., Schmid, T., \& Floyd, S. (2008). The middle management perspective on strategy process: Contributions, synthesis and future research. Journal of Management, 34(6), 1190-1221. 